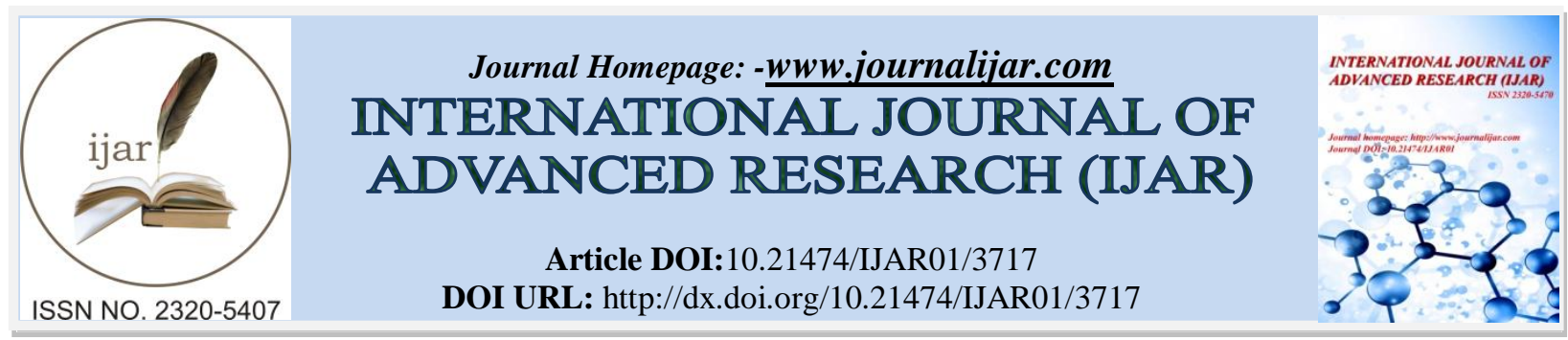

RESEARCH ARTICLE

\title{
SUSTAINABLE MANAGEMENT OF FOREST ECOSYSTEMS IN E. AFRICAFOR IMPROVED LIVELIHOODS AND ENVIRONMENTAL RESILIENCE.
}

\author{
George Ouma Ochola, Daniel Odinde Nyamai and Steve Omari Ngodhe \\ Rongo University, P.O. Box 103-40404, Rongo, Kenya.
}

\section{Manuscript Info \\ (n.......................... \\ Manuscript History \\ Received: 15 January 2017 \\ Final Accepted: 03 February 2017 \\ Published: March 2017 \\ Key words:- \\ Sustainable forest ecosystem; integrated land-use management; sustainable productive environment; agroforestry; and biodiversity conservation.}

\section{Abstract}

Forest ecosystems play a pivotal role in socio-economic development and ecological stability. Critical role played by forests ecosystem cannot be over-emphasized noting the current commitment by UN Member States under COP 21 of 2015 on climate change adaptation and mitigation. Forests provide a pool of genetic resources, timber, fruits, medicine, fodder, regulating services such as flood and climate regulation; cultural services, aesthetic, recreational values; and supporting services including primary production, carbon sequestration, nutrient cycling, soil formation and biodiversity conservation. They are critical in provision of renewable energy that majority of African households still depend on. Trees are important in integrated soil, water and biodiversity conservation and in mitigating climate change and variability. Forestry and agroforestry management principles are inherently geared towards harnessing the benefits of natural resources and biodiversity for livelihoods and sustainable productive environment. The study presents results of the existing challenges and opportunities facing forests ecosystem management, agricultural production and biodiversity conservation owing to human pressure on land-use and natural resources in E. Africa. It is concentrated on the analysis of three major pathways for sustainable forests ecosystem: (i) reducing pressure on natural forests; (ii) providing habitat for native plant and animal species; and (iii) forests and agroforestry systems for integrated land use management and fragmented landscapes. The review proposes a paradigm shift to accelerate the current low investment in these resources while promoting strategies that facilitate the mainstreaming of forestry and agroforestry management, including biodiversity conservation in the sub-region's development agenda. It identified the following action plans to be fast-tracked in the subregion: Design, develop and disseminate improved technologies and innovations, management plans for sustainable and equitable management of forests and agroforestry resources; Enhance productivity and conservation of agro-ecosystems using trees and agroforestry practices /technologies for socio-economic benefits and environmental services; Facilitate the development of policy options and institutional innovations for enhanced investment in forestry and agroforestry and allied natural resources based enterprises; Strengthen the capacity and governance framework for effective and sustainable 
management of forestry and agroforestry resources; and Promote awareness and access to knowledge and information for improved and adaptive management and innovations, including utilization.

Copy Right, IJAR, 2017,. All rights reserved.

\section{Introduction:-}

The General Assembly of the United Nations adopted the definition of Sustainable Forest Management in December 2007as a dynamic and evolving concept aims to maintain and enhance the economic, social and environmental value of all types of forests, for the benefit of present and future generations. It is characterized by seven elements, including: (i) extent of forest resources; (ii) forest biological diversity; (iii) forest health and vitality; (iv) productive functions of forest resources; (v) protective functions of forest resources; (vi) socio-economic functions of forests; and (vii) legal, policy and institutional framework(International Union for Conservation of Nature, 2012).

Developments in forest management over the past decades have focused on progress towards Sustainable Forest Management (SFM), an approach that balances environmental, socio-cultural and economic objectives of management in line with the "Forest Principles" adopted at the United Nations Conference on Environment and Development (UNCED) in 1992.

Parallel efforts in environmental conservation, particularly within the framework of the Conservation on Biodiversity, have led to the development of the Ecosystem Approach (EA) as a framework and holistic approach for the conservation and sustainable use of biological diversity and its components in all types of ecosystems (Metteet al., 2003).

Africa as a continent is rich in natural resources. Its land, water, and forests underpin the sustained productivity of food crops and livestock on which millions of Africans depend directly for their livelihood and survival (Global Environment Facility, 2011). These resources are major assets on which most countries depend for economic growth and sustainable development (GEF, 2011).

Undoubtedly, the risk of expanding land degradation and desertification, increased deforestation, and water scarcity threatens to hasten a major global environmental crisis. In Kenya, it is not an entirely surprising statistic that about $12 \%$ of the land areas which was originally covered by closed canopy forests has been reduced to a mere $1.7 \%$ of its original size. This is attributed to population pressure for settlements, infra-structure, demand for wood products and conversion to agriculture Government of Kenya (GOK, 2013).

Forests harbour two thirds of all terrestrial animal and plant species (IUCN, 2012). They provide food, oxygen, shelter, recreation, and spiritual sustenance.They are the source for over 5,000 commercially-traded products, ranging from pharmaceuticals to timber and clothing. The biodiversity of forests, variety of genes, species, and forest ecosystems underpins these goods and services, and is the basis for long-term forest health and stability. The Convention on Biological Diversity (CBD) addresses the conservation and sustainable use of forest biodiversity through a comprehensive programme of work, adopted in 2002 and revised in 2008. Many of the activities of the programme of work promote poverty reduction and creation of sustainable livelihoods(IUCN, 2012).

Despite the major roles played by forests such as provision of goods and ecological services, waste assimilation and aestheticism, it is threatened by habitat modification and fragmentation, a reduction in vegetation cover and species diversity, and over-exploitation and competition from invasive species, mainly as a consequence of human population growth. The high level of deforestation is attributed to the need for woodfuel for home consumption but more so for commercial purposes where the charcoal is sold to urban dwellers in major towns. Further, there is limited information and knowledge on appropriate management regimes of the forests and also non-availability of suitable germplasm for propagation of biological species(GEF, 2011). This scenario is compounded by limited focus and priority on the forests by implementing agencies both in the government and NGO sector. Community participation is also limited in the management and utilization of such resources.

The review involved identification andassembling of relevant documents; assessment of the documents using review checklist developed in line withthe emphasis on the sustainable forest managementand focus areas.Past GIS database was also reviewed and keysites of major environmental significance identified. 


\section{Challenges facing forest ecosystem:-}

It is widely acknowledged that forests are faced with a myriad of political, socio-economic, and environmental challenges with profound implications for their sustainable management and development. Forests and associated biodiversity, which underpins the livelihoods of the majority of the rural poor, is being destroyed irreversibly by human activities. The situation is exacerbated by climate variability and change, whose effects are already being witnessed in the region in the form of variable water supplies, lengths of growing season, extreme weather events (floods, droughts), and changing habitats. How to deal with these trends and challenges to sustainably manage these resources so as to conserve, utilize and improve livelihoods and the environment in East African forest ecosystems remains a great question.

The review findings reveal that degradation and loss of forests and associated habitats and the species that they support is a result of a wide range of natural and man-made causes interacting at different levels and intensities on the forest ecosystems. TheMillennium Ecosystem Assessment (MEA) report (2005) for instance asserted that an estimated $70 \%$ of natural habitats in the Mara River Basin have been converted over time to farmland and other forms of settlement. Table (1) shows the areas in Kenya and rate of change in forest cover from 1990 to 2010

Table 1:- Areas of Forest in Kenya and Rate of Change since 1990.

\begin{tabular}{|c|c|c|c|c|c|}
\hline \multirow{2}{*}{$\begin{array}{l}\text { Category of forest resource (using FAO } \\
\text { definitions) }\end{array}$} & \multicolumn{4}{|c|}{ Area ('000 Ha) } & \multirow{2}{*}{$\begin{array}{l}\text { Annual change } \\
1990 \text { to } 2010 \text { ('000 } \\
\text { Ha) }\end{array}$} \\
\hline & 1990 & 2000 & 2005 & 2010 & \\
\hline Indigenous closed Canopy Forest & 1240 & 1190 & 1,165 & 1,140 & -5 \\
\hline Indigenous Mangroves & 80 & 80 & 80 & 80 & 0 \\
\hline Open woodlands & 2150 & 2100 & 2075 & 2,050 & -5 \\
\hline Open woodlands & 170 & 134 & 119 & 107 & -3.15 \\
\hline Private Plantation forests & 68 & 78 & 83 & 90 & +1.1 \\
\hline $\begin{array}{l}\text { Sub-total Forest land (total of above } \\
\text { categories) }\end{array}$ & 3708 & 3582 & 2357 & 3,467 & -12.05 \\
\hline Bush-land & 24800 & 24635 & 24570 & 24,510 & -14.5 \\
\hline Farms with Trees & 9420 & 10020 & 10320 & 10,385 & +48.25 \\
\hline Total Area of Kenya & 58037 & 58037 & 58037 & 58,037 & 0 \\
\hline
\end{tabular}

Source: (GoK, 2013).

Over the past three decades, large areas of forest reserves have been officially "de-gazetted" and unofficially converted to other uses, mainly agriculture, and the remaining protected indigenous forests managed by for example Kenya Forest Service (KFS) in Kenya. The reviewestablished that logging, both legal and illegal, of valuable timber trees results in reduced carbon stocks and degraded biodiversity values. Forests on community trust lands under the control of local authorities continue to be degraded and destroyed through over-exploitation for timber, poles, charcoal and fuel wood, and through unregulated grazing and clearance for agriculture; depicting what the previous studies termed as "tragedy of the commons".

Matiet al., 2005 asserted that significant changes on land cover have taken place. According to their study, it is clear thatforests, shrub land, grassland, and savannah reduced by $32 \%, 34 \%, 45 \%$, and $26 \%$ respectively as shown in table 2. Despite efforts made to protect forest biodiversity in the region pressure on forest resources is still on the rise due to population increase and hence need for more land for settlement and farming.

Table 2:- Extent of land use/cover changes in the Mara river basin between 1973 and 2000

\begin{tabular}{|l|l|l|l|l|l|}
\hline Land cover type & $\mathbf{1 9 7 3}\left(\mathbf{k m}^{2}\right)$ & $\mathbf{1 9 8 6}\left(\mathbf{k m}^{2}\right)$ & $\mathbf{2 0 0 0}\left(\mathbf{k m}^{2}\right)$ & Change & \multicolumn{2}{l|}{} \\
\cline { 5 - 6 } & & & & $\mathbf{K m}$ & $\mathbf{2}$ \\
\hline Forest & 1008 & 893 & 689 & -319 & -32 \\
\hline Tea/ open forest & 621 & 1073 & 1948 & +1327 & +214 \\
\hline Agricultural land & 826 & 1617 & 2504 & +1678 & +203 \\
\hline Shrubland & 5361 & 5105 & 3546 & -1815 & -34 \\
\hline Grassland & 2465 & 1621 & 1345 & -1120 & -45 \\
\hline Savannah & 3163 & 2867 & 2354 & -809 & -26 \\
\hline Wetlands & 286 & 604 & 1394 & +1109 & +387 \\
\hline Water bodies & 104 & 54 & 55 & -49 & -47 \\
\hline
\end{tabular}

Source: Mutieet al. 2005 
Key challenges to forest ecosystems:-

Expanding agriculture:The review established general soil fertility of forest ecosystemswhich has attracted settled agriculture, including commercial food and horticultural plantations. It is noted that the soils in upland and lowland Riverine forests patches are more fertile than those of surrounding farmlands and woodlands and hence face pressure to be converted for agriculture.

Charcoal production and firewood harvesting: Although not well quantified, the business of charcoal production has heavily impacted the forests ecosystems. Away from towns and roads this threat is much less important as local people use firewood for cooking. Most firewood is collected from trees and bushes outside the protected forest areas.

Uncontrolled fires: Widespread pastoralism for example in Mara River Basin forests ecosystem particularly with Maasai community in both Kenya and Tanzania threaten woodland and shrub land forest vegetation of being cleared for pastures. Although forest fires are a natural phenomenon,majority that occur are started by pastoralists and people who use the fire to clear farmland, drive animals for hunting, collect honey, and remove tsetse flies from an area. Some other fires are started accidentally, for example from cigarettes thrown from passing vehicles or by pedestrians. These occasional fires destroy forest and other biodiversity. Over time and with frequent and intense burning it is believed that lowland forests ecosystems and thicket vegetation is converted to more fire-adapted vegetation types. This results in a loss of the narrowly endemic forests ecosystem species and their replacement by wide-ranging invasive species.

Illegal and unsustainable logging: The commercial logging of forests ecosystem tree species occurs mainly for example in Mau Forest, Kenya and in the middle and lower Riverine forests of the Mara river Basin (MRB) forests ecosystem. Logging using pit-sawing techniques occurs in forests ecosystem where timber trees remain. Many forests have already been logged to exhaustion, particularly heavy exploitation for round wood. Logging of the valuable trees is often the first major disturbance to a forest, which then progresses to fire wood collection and charcoal burning, and in the worse cases to clearance for agricultural use.

Unplanned settlement: Over much of forests ecosystem the expansion of settlements is only partly planned. For example, in the Mau forests, illegal settlers have interfered with the catchment vegetation which is the main sources of water to the Mara River. In some of the protected forests ecosystem of Kenya and Tanzania (both Forest Reserves and traditionally protected forest areas), settlements have been established within the boundaries of the reserve. When this happens, farming activities also start and there can be much damage to the habitats. Similarly, the expansion of tourism facilities into some forests ecosystem is also an issue for concern.

Minor threats: Some threats, such as invasive species, are considered to be relatively minor. However these threats need to be carefully monitored to ensure that action is taken so that they do not become more significant.

Causes of Forest Biodiversity loss:-

Limited alternative economic activities: A significant proportion of the population in Kenya and Tanzania, particularly the communities relying on agriculture and pastoralism for their livelihoods. Direct threats from agricultural expansion and associated fires, in particular, are linked to poverty and limited alternative economic activities in rural areas. As subsistence agriculture is the primary livelihood strategy for most people in rural areas, the need for land puts negative pressure on forests, even though many forest products are used and valued by local people. A high level of direct reliance on forest products to sustain livelihoods contributes to their overuse in some areas. The lack of affordable energy alternatives also drives the urban demand for charcoal.

Demographic changes: Demographic changes combined with uncontrolled settlement increases overall direct pressures on land, timber and non-timber forest resources. Demand for additional farmland for subsistence agriculture also rises. Population increases are also linked to habitat degradation associated with increased demand for firewood, charcoal, timber, building materials and bush meat.

Declining respect for traditional forest protection systems: Small areas of forests have traditionally been conserved as sacred sites. These areas have been protected by community elders but are now threatened and some cases being destroyed by recent migrants who do not necessarily owe allegiance to traditional authorities. A decline 
in the respect for elders among other members of the local population is causing further pressures to convert these forests to farmland.

Limited institutional capacities and financial support: While decentralization efforts are focusing more attention and responsibilities at local levels, the local natural resource management agencies are often understaffed, poorly funded, and have limited capacity to adopt new management approaches such as 'participatory forest management'. Financial support for capacity building and management activities, including management of protected areas, and enforcement of regulations on commercial resource extraction, is also limited.

Limited Consideration of Environmental Impacts of Economic Development Policies: National and Local Governments tend to give priority to economic development activities and will permit the clearance of natural habitats to establish mining, tourism facilities, roads, and agricultural projects. Given the poverty levels in Kenya and Tanzania, such a development focus is understandable. However, there remains considerable scope for undertaking development that is less environmentally damaging through enhanced integration of conservation objectives in development planning and consideration of environmental impacts.

Inadequate Capacity to Enforce Regulations on Commercial Extraction:Forest ecosystemssuffers inadequate capacity to enforce forest rules and regulations, such as those on charcoal and timber production. For instance, the MRB Ecoregion Illegal activities are both depleting natural resources and limiting the economic value of these activities that is captured by the national economies.

Legal Issues and Land Tenure:The existence of different land tenure systems in East Africa contributes to loss of forest biodiversity. In Kenya for example, the current land tenure system leaves a large percentage of rural population without secure title, especially those on the Trust Lands that make up a majority of the land in the country. This limits incentives for people's long-term stewardship of these lands. In Tanzania, recent changes in the Land Law (1999) mean that it is now possible for villages to gain title deeds for their village lands, and also for individuals to obtain deeds for land. This is a change from the past system where land was controlled by the government, and may offer better possibilities for the management of forest resources at the village level.

Inadequate Institutional Coordination and Integration of Sectoral Policies: At the national level, conflicting objectives and policies among government ministries and departments have also contributed to the loss of habitats across the region. In both Tanzania and Kenya there are over 20 sectoral policies that either directly or indirectly affect forest management and conservation practices, with no clear mechanism for ensuring linkages between these different policies and Acts. However, the governments of Kenya and Tanzania have started putting mechanisms in place to address this issue.

\section{Sustainability Management Issues:-}

Despite the abundance and huge potential of the sub-region's forest and tree resources for sustainable development and provision of environmental services, the Partner States have not invested adequately in these resources in pursuit of effective and sustainable management to bring about the required transformation for improvement in livelihoods. To change this trend, there is a urgent need to increase investment in strategies to facilitate the mainstreaming of forestry and agroforestry management, including biodiversity conservation in the sub-region's development agenda. Unprecedented degradation pressure arising from human activities and climate change and variability put forests and agroforestry systems at risk. Principal threats identified include: land use and land cover changes, mainly through conversion of natural forest ecosystems to agricultural land and settlement and loss of flora due to adverse effects of climate change and variability. It is also feared that with increasing population pressure, land clearing and deforestation will continue which is a threat to genetic diversity due to loss of species.

\section{Conclusion:-}

The importance accruing from forest ecosystems cannot be over-emphasized. The riparian communities appreciate what forest ecosystems do to them. The only challenge is sustainable management of this natural resource. There is therefore need to collectively strive by partner states to ensure that their utilization, activities and management of the forest resources are geared toward sustainability.

\section{Recommendations for sustainable forest management:-}

- Designing, developing and disseminating improved technologies and innovations, management plans for sustainable and equitable management of forests and agroforestry resources; 
- Enhancing productivity and conservation of agro-ecosystems using trees and agroforestry practices / technologies for socio-economic benefits and environmental services;

- Facilitating the development of policy options and institutional innovations for enhanced investment in forestry and agroforestry and allied natural resources based enterprises;

- Strengthening the capacity and governance framework for effective and sustainable management of forestry and agroforestry resources; and

- Promoting awareness and access to knowledge and information for improved and adaptive management and innovations, including utilization;

\section{References:-}

1. FAO (2003). Sustainable Forest Management and the Ecosystem Approach: Two Concepts, One goal by Wilkie M.L., Holmgren P. and Castaneda F. Forest Management Working Papers, Working Paper FM 25. Forest Resources development Service, Forest Resources Division. FAO, Rome (Unpublished)

2. GEF, (2011). Land, Water, and Forests:Assets for Climate Resilient Development in Africa

3. GOK, (2013).Ministry of Forestry and Wildlife:Analysis of drivers and underlying causes of forest cover change in the various forest types of Kenya. Consultancy Services.

4. IUCN, (2012). A Good Practice Guide Sustainable Forest Management, Biodiversity and Livelihoods

5. Kombo, D. and Orodho, J., (2002).Proposal and Thesis Writing, Pauline publications Africa, Nairobi, Kenya.

6. Kothari, C.R., (2009).Research Methodology-Methods and Techniques, NewDelhi,Wiley Eastern Limited.

7. Mati, B. M., Mutie, S., Home, P., Mtalo, F., and Gadain, H. 2005. Land Use Changes in the Trans-Boundary Mara Basin: a threat to pristine wildlife sanctuaries in East Africa. 8th International River Symposium, Brisbane, Australia.

8. MEA (2005).Ecosystems and Human Well-Being: Policy Responses. Volume 3, Ch. 8. Island Press, Washington, DC.

9. Mugenda, O.M. and Mugenda, A.G. (2003) Research Methods: Quantitative and Qualitative Approaches. Acts Press, Nairobi.

10. Mutie1S.,Bancy M., Home1P., MtaloF. andGadain H. (2005). Land Use Changes in the Transboundary Mara Basin:A Threat to Pristine Wildlife Sanctuaries in East Africa. Nairobi, Kenya

11. UNEP, (2011). Towards a Green Economy: Pathways to Sustainable Development and Poverty Eradication: ASynthesis for Policy Makers, www.unep.org/greeneconomy. 